\title{
Overview of SOFC Anode Interactions with Coal Gas Impurities
}

\author{
O. A. Marina ${ }^{\mathrm{a}}$, L. R. Pederson ${ }^{\mathrm{a}}$, R. Gemmen ${ }^{\mathrm{b}}$, K. Gerdes ${ }^{\mathrm{b}}, \mathrm{H}$. Finklea ${ }^{\mathrm{c}}$, and I. B. Celik ${ }^{\mathrm{c}}$ \\ ${ }^{a}$ Pacific Northwest National Laboratory, Richland, Washington 99352, USA \\ ${ }^{\mathrm{b}}$ National Energy Technology Laboratory, Morgantown, West Virginia 26507, USA \\ ${ }^{\mathrm{c}}$ West Virginia University, Morgantown, West Virginia 26506, USA
}

An overview of the results of SOFC anode interactions with phosphorus, arsenic, selenium, sulfur, antimony, and hydrogen chloride as single contaminants or in combinations is discussed. Tests were performed using both anode- and electrolyte-supported cells in synthetic and actual coal gas for periods greater than 1000 hours. Post-test analyses were performed to identify reaction products formed and their distribution, and compared to phases expected from thermochemical modeling. The ultimate purpose of this work is to establish maximum permissible concentrations for impurities in coal gas, to aid in the selection of appropriate coal gas clean-up technologies.

\section{Introduction}

Efficiencies greater than 50 percent (higher heating value) have been projected for solid oxide fuel cell (SOFC) systems fueled with gasified coal, even with carbon sequestration. Multiple minor and trace components are present in coal that could affect fuel cell performance, however, which vary widely depending on coal origin and type, Figure 1. Minor and trace components have been classified into three groups: elements with low volatility that are likely to remain in the ash, elements that will partition between solid and gas phases, and highly volatile elements that are unlikely to condense. Those in the second group are of most concern. In the following, an overview of the results of SOFC anode interactions with phosphorus, arsenic, selenium, sulfur, antimony, and hydrogen chloride as single contaminants or in combinations is discussed. Tests were performed using both anode- and electrolyte-supported cells in synthetic coal gas. The ultimate purpose of this work is to establish maximum permissible concentrations for impurities in coal gas, to aid in the selection of appropriate coal gas clean-up technologies.

\section{Results and Discussion}

\section{Thermodynamic analysis of trace species}

Volatile species of trace coal elements are derived from coal during the gasification process. The species arriving at the anode depend on the coal type and specific processing of the synthesis gas (syngas) from gasification through cleanup. The 


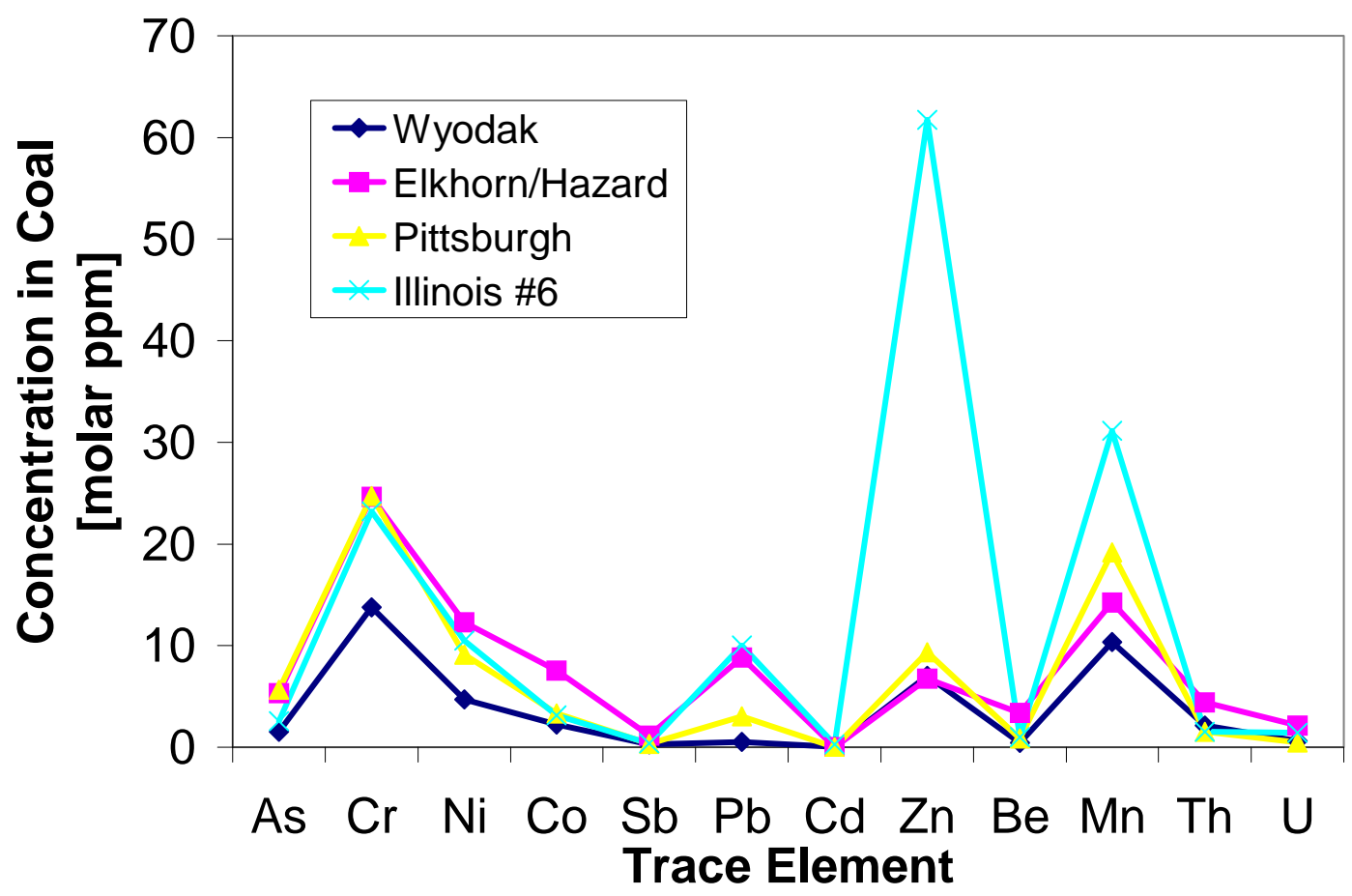

Figure 1. Distribution of trace elements in some of the U.S. gasified coal streams.

thermodynamic conditions of the syngas can be used to model the partitioning of trace elements between solid and gaseous phases in the process system, and also to model thermodynamically stable phases resulting from trace material interaction in the anode of the SOFC. The models can be used to predict nickel consumption of the anode as a function of total trace material exposure.

Figure 2 illustrates the partitioning of elements between condensed phases and gaseous phases, with the ordinate reflecting the percent of $\equiv$ nlet mass of a given element which exits the gas cleanup as some gas phase specie. Error bars indicate the range of calculated mass through the full operating temperature parameter space. Elements such as $\mathrm{Cr}, \mathrm{V}, \mathrm{Zn}$, Se, and $\mathrm{Pb}$ are expected to be separated from the gas stream in the cleanup unit, while elements such as $\mathrm{Cl}, \mathrm{P}, \mathrm{As}$, and $\mathrm{Hg}$ are almost always observed exclusively in the gas phase. Elements such as $\mathrm{S}, \mathrm{Cd}$, and $\mathrm{Sb}$ are partitioned between both phases to an extent that depends on the cleanup operating conditions.

Thermodynamic simulations of gasifier / SOFC systems require careful normalization to ensure meaningful cross comparison of the selected operating conditions. Initial bulk syngas compositions were determined by surveying 15 different gasification units. Trace elements were loaded into the syngas and molar flows were normalized to preserve a constant carbon-to-trace element ratio independent of gasifier (for this work the trace loading of an entrained gasifier as given by Trembly etl al. [1] was used.) The gases were thermally equilibrated in a simulated non-catalytic scrubbing process that removes 


\section{Percent of Trace Elements that Pass through Cleanup Stage}

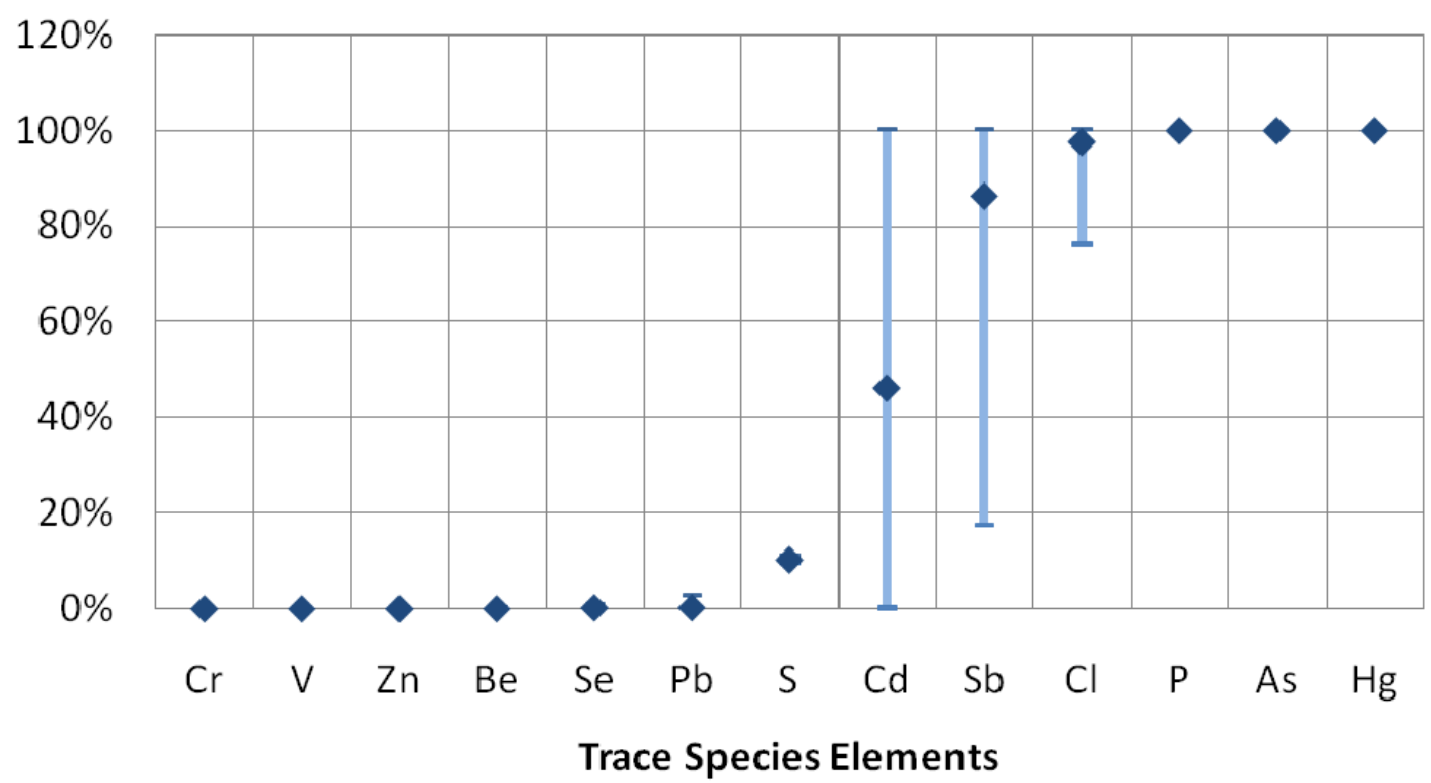

Figure 2. Partitioning of trace elements after warm gas cleanup calculated by NETL.

liquid and solid products. Prior to entering the anode, an equilibration check was made to ensure carbon is not formed, and water was added to completely suppress carbon as necessary. The Nernst potentials of the resulting flows were determined, and the molar flow rates were calculated to achieve a common power output for all gasifier cases. An operating time was specified and the resultant quantity of the gas was finally equilibrated with the anode nickel to determine the resulting solid phases.

The trace elements arsenic, phosphorus, and antimony alone were predicted to strongly interact with the nickel anode to produce bulk nickel arsenides, posphides, and antimonides, Figure 3. All other species either are removed upstream of the anode, or pass through the anode unaffected. Results generally indicate that the extent of nickel consumption is sensitive to the operating temperature of the SOFC, with higher operating temperatures of $900^{\circ} \mathrm{C}$ showing greater resistance to secondary phase formation than operating temperatures of $700^{\circ} \mathrm{C}$. The bulk syngas composition also affects the total consumption of nickel, with fewer secondary phases generated in the presence of a greater steam content. Secondary anode phase formation was weakly sensitive to the operating temperature of the simulated cleanup system, which ranged from $315^{\circ} \mathrm{C}$ to $400^{\circ} \mathrm{C}$. Total nickel consumption in the anode ranged from $12 \%$ to $30 \%$ after 5000 hours of operation at $800^{\circ} \mathrm{C}$ and ranged from $25 \%$ to $61 \%$ after 3000 hours of operation at $700^{\circ} \mathrm{C}$ for the various gas streams and cleanup conditions tested. These nickel consumption rates are supported by laboratory testing on simulated syngas containing specific impurities. 


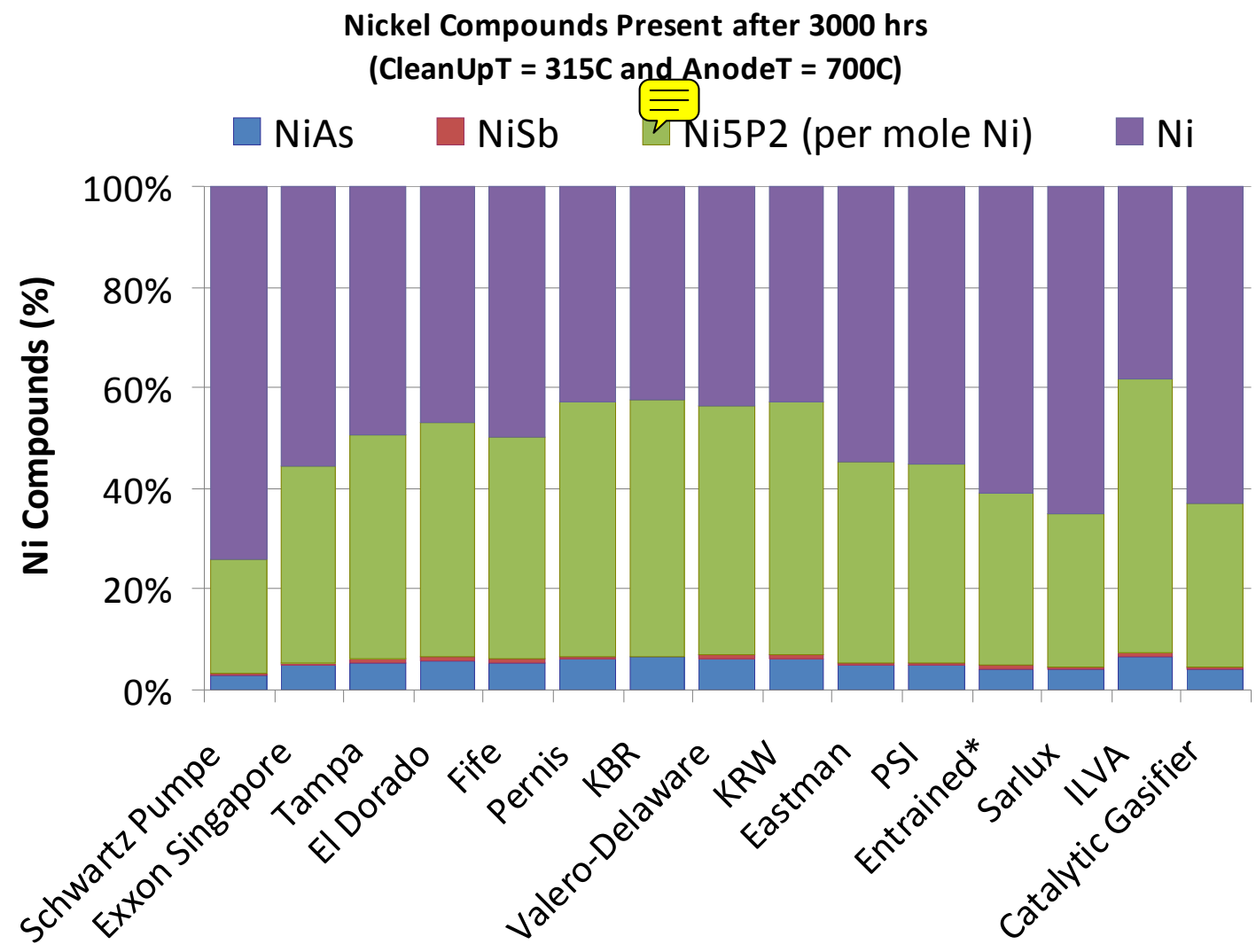

Figure 3. Variations in secondary phase formation at $800^{\circ} \mathrm{C}$ for different coals containing different levels of contaminants, derived by NETL. Although not all experimentally were confirmed, for modeling purpose $\mathrm{NiAs}, \mathrm{NiSb}$ and $\mathrm{Ni}_{5} \mathrm{P}_{2}$ were chosen.

\section{Effect of phosphorus}

The interaction of phosphorus in synthetic coal gas with the nickel-based anodes in anode-supported and electrolyte-supported solid oxide fuel cells has been investigated. In all experiments, there was an immediate irreversible performance degradation after adding $10 \mathrm{ppm}$ of $\mathrm{PH}_{3}$, Figure 4. Rates of degradation were somewhat dependent on the cell operating voltage, and were on the order of $1 \mathrm{~mW} / \mathrm{cm}^{2} / \mathrm{hr}$, or $0.4 \%(+/-0.3 \%)$ per hour. Periodic impedance measurements revealed a slight increase in the ohmic resistance and a significant increase in the polarization resistance accompanying the power degradation. The resistivity of the anode, obtained via in-situ Van der Pauw measurements of the anode, did not increase significantly during the degradation [2]. Post-mortem SEM analysis revealed the severe nickel migration to the surface of the anode and into pores in the anode structure, Figure 5, mostly in a form of $\mathrm{Ni}_{3} \mathrm{P}$ as verified by XRD analysis. Both reduced and oxidized forms of phosphorus were detected in the surface layer by XPS analysis, while only oxidized phosphorus, possibly phosphate, was observed in the active anode. No dependence on current flow on the nickel phosphide migration was observed [3]. 


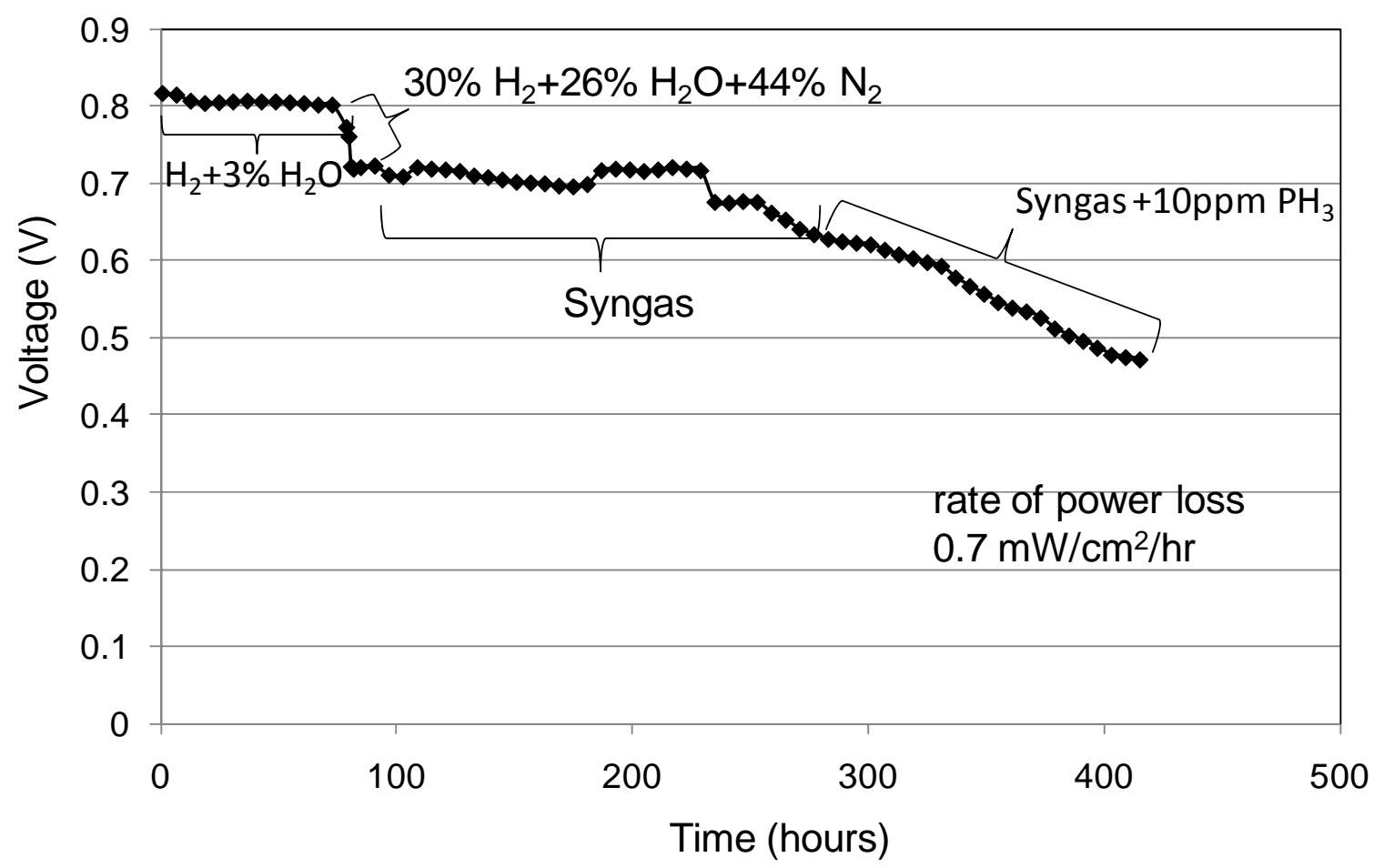

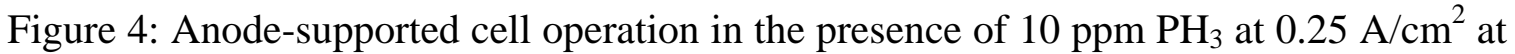
$800^{\circ} \mathrm{C}$ as obtained by a WVU team.
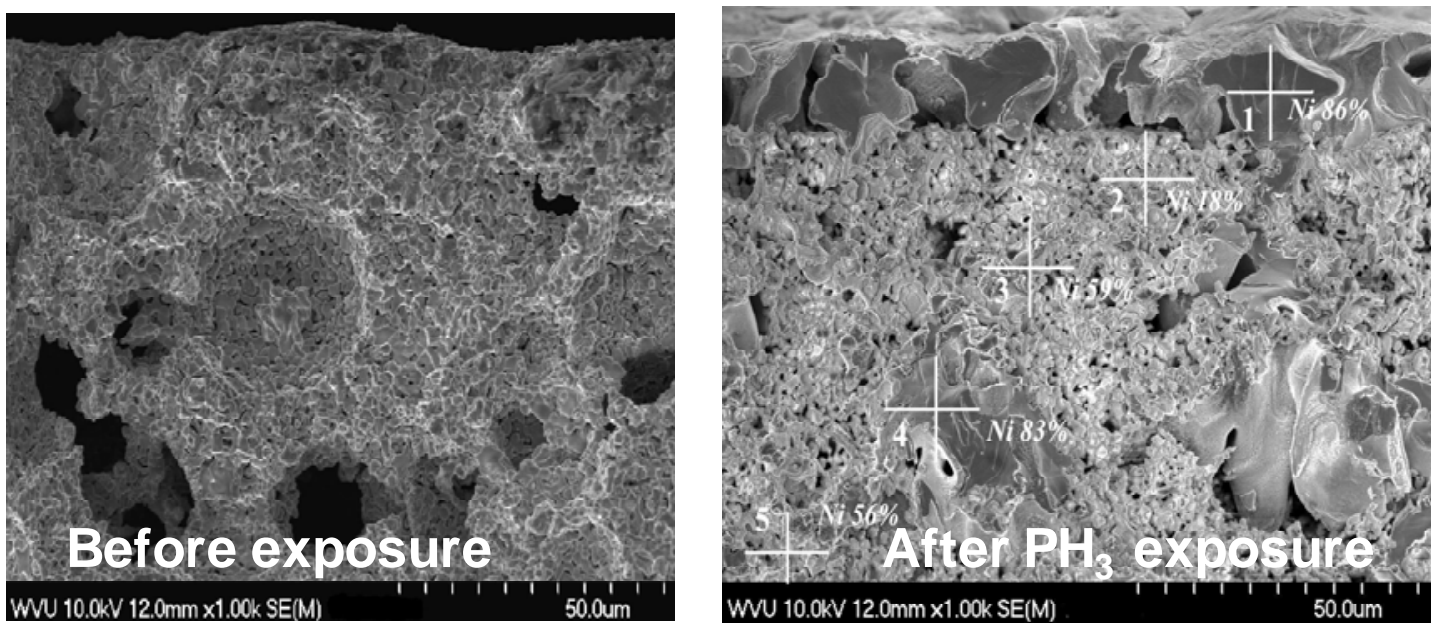

Figure 5. SEM images of the Ni/YSZ anode support before and after exposure to $\mathrm{PH}_{3}$ as obtained at WVU test facilities. 
Two primary modes of degradation were revealed [3]. The first one was the formation of a series of bulk nickel phosphide phases, as given in Figure 5. A second mode of degradation was attributed to surface diffusion of phosphorus to the active anode/electrolyte interface to form an adsorption layer. Direct evidence for the presence of such an adsorption layer on nickel was obtained by surface spectroscopies on fracture surfaces.

\section{Effect of arsenic}

$\mathrm{Ni} / Y S Z$ exposures cell to $0.5-10 \mathrm{ppm}$ of arsenic at $700-800^{\circ} \mathrm{C}$ in synthetic coal gas led to the irreversible anode- and electrolyte-supported cell degradation, often followed by complete failure. A major mode of degradation was loss of electronic percolation, the result of alteration phase formation, grain growth, and inducement of micro-fractures within the affected portions of the anode support. Arsenic concentrations of $10 \mathrm{ppb}$ or less were estimated to result in acceptable rates of fuel cell degradation [4].

Nickel was found to interact more strongly with arsenic than with phosphorus at similar concentrations. When added in a combination with phosphorus, arsenic was captured on the outer surface of the Ni/YSZ anode, while phosphorus migrated to greater depths, Figure 6.

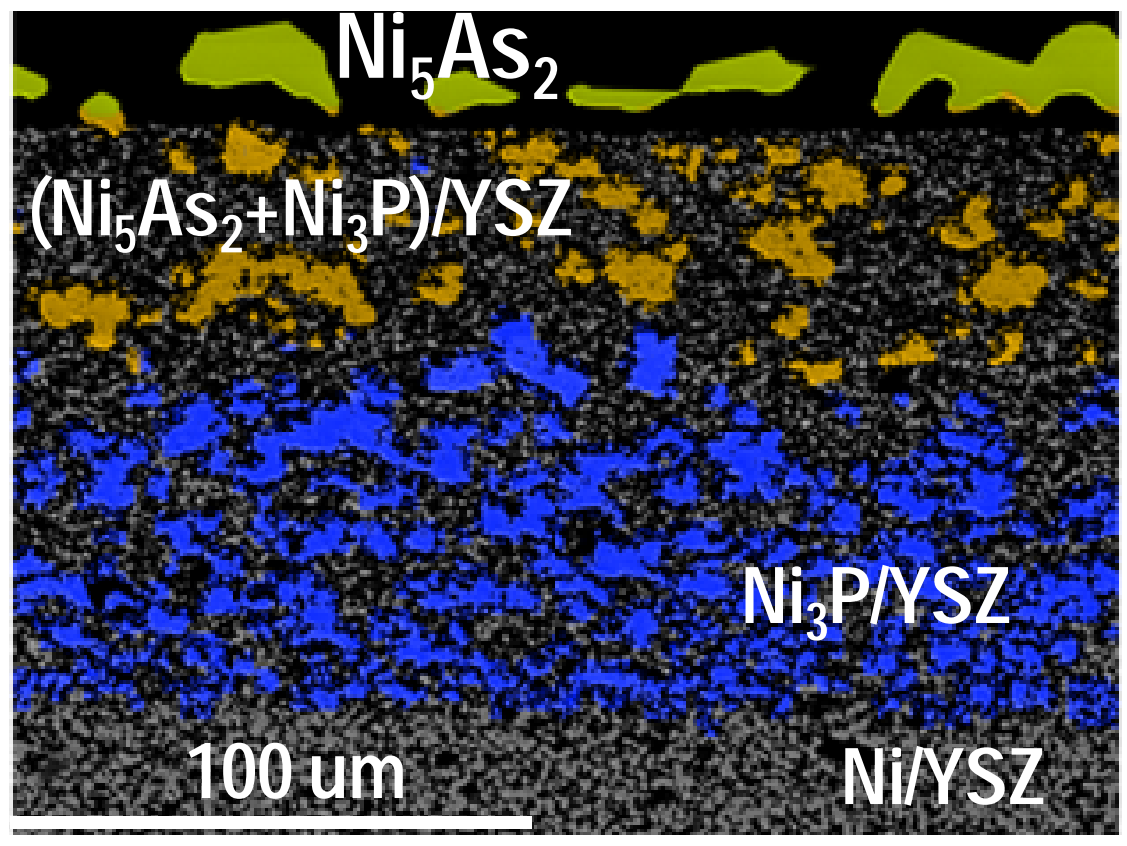

Figure 6. Cross-sectional SEM image of Ni/YSZ combined with the elemental maps

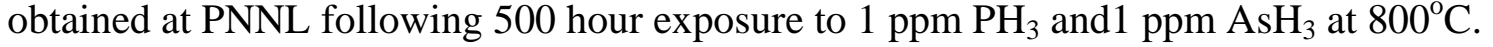




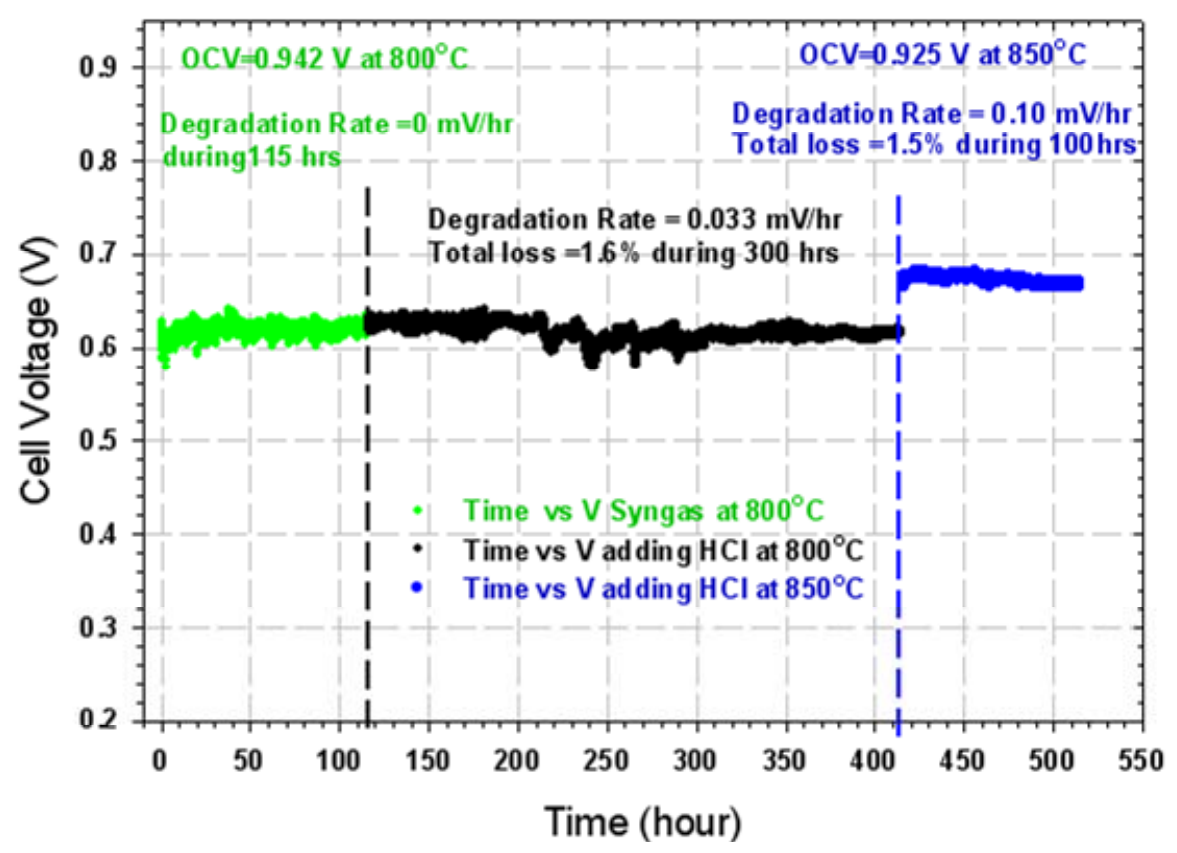

Figure 7. WVU's anode-supported cell during exposure to $100 \mathrm{ppm} \mathrm{HCl}$ in syngas at 800 and $850^{\circ} \mathrm{C}$.

\section{Effect of antimony}

Rapid but minor degradation occurred immediately on exposure of both electrolyteand anode supported cell degradation upon exposure to $1 \mathrm{ppm}$ antimony in coal gas at $800^{\circ} \mathrm{C}$, followed by a steady state performance. Electrodic resistances were found to increase, indicating a formation of an antimony adsorption layer at the active interface. Long-term tests revealed nickel transformation to $\mathrm{Ni}_{3} \mathrm{Sb}, \mathrm{Ni}_{5} \mathrm{Sb}_{2}$ and $\mathrm{NiSb}$, followed by cell failure due to electronic percolation loss.

\section{Effect of selenium and sulfur}

Nickel-sulfur and nickel-selenium interactions were found to be much weaker than those with antimony, arsenic or phosphorus. While no second phases were typically detected in the temperature range $600-800^{\circ} \mathrm{C}$ with $5 \mathrm{ppm}$ or less of the impurity, cell performance loss was substantial, with a rapid increase in the area specific resistance of $40-300 \%$ and decrease in power output of $10-70 \%$. Nearly complete anode recovery

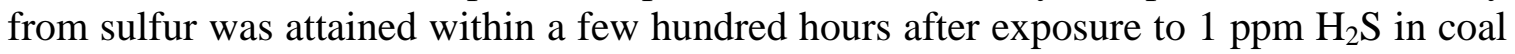
gas, while recovery from selenium exposure was incomplete. At high polarization losses, oscillatory behavior was observed, where cell performance fell rapidly and then regained the activity. At even higher polarization losses, irreversible cell failure occurred in the presence of as low as $0.5 \mathrm{ppm} \mathrm{H}_{2} \mathrm{Se}$. This was explained by the $\mathrm{Ni}_{3} \mathrm{Se}_{2}$ formation at the active anode/electrolyte interface as confirmed by SEM analysis [5]. 


\section{Effect of hydrogen chlorine}

SOFCs showed very little degradation in the presence of $100 \mathrm{ppm}$ or less of hydrogen chloride, Figure 7. Cell performance recovered fully upon termination of hydrogen chloride exposure. Formation of new solid phases was not observed, nor were they predicted from thermodynamic modeling [6].

\section{Acknowledgments}

A. Martinez (NETL) is thanked for preparing Figures 1 and 2. The authors would like to acknowledge technical assistance and fruitful discussion with many researchers from PNNL, NETL, and WVU. Support for this work is provided by the U.S. Department of Energy, Office of Fossil Energy, National Energy Technology Laboratory through the Solid-State Energy Conversion Alliance (SECA) program.

\section{References}

1. J. P. Trembly, R. S. Gemmen, D. J. Bayless, J. Power Sources, 163, 986 (2007).

2. O. Demircan, C. Xu, J. Zondlo, H.O. Finklea, J. Power Sources, 194, 214 (2009).

3. O.A. Marina, C.A. Coyle, E.C. Thomsen, D.J. Edwards, G.W. Coffey, L.R. Pederson, Solid State Ionics, in print (2010). doi:10.1016/j.ssi.2010.01.018

4. C.A. Coyle, O.A. Marina, E.C. Thomsen, D.J. Edwards, C.D. Cramer, G.W. Coffey, L.R. Pederson, J. Power Sources, 193, 730 (2009).

5. O. A. Marina, L. R. Pederson, C. A. Coyle, E. C. Thomsen, G. W. Coffey, ECS Transactions, 25, 2125 (2009).

6. J.P. Trembly, R.S. Gemmen, D.J. Bayless, J. Power Sources, 169, 347 (2007). 